\title{
PENERAPAN MODEL PEMBELAJARAN BERBASIS MASALAH DALAM PEMBIASAN CAHAYA PADA LENSA TERHADAP HASIL BELAJAR SISWA DI KELAS VIII SMP NEGERI 5 KETAPANG
}

\author{
Stepanus Sahala, Abdus Samad \\ Pendidikan Fisika, PMIPA, Universitas Tanjungpura
}

\begin{abstract}
Abstrak
Penelitian ini bertujuan untuk mengetahui penerapan model pembelajaran berbasis masalah dalam pembiasan cahaya pada lensa terhadap hasil belajar siswa di kelas VIII SMP Negeri 5 Ketapang. Bentuk penelitian yang digunakan adalah Quasy Experiment, dengan rancangan Pretest Posttest Control Group Design. Pengambilan sampel yang digunakan dalam penelitian ini adalah dengan teknik Purposive Sampling. Sampel penelitian yaitu kelas VIII B sebagai kelas kontrol dan VIII A sebagai kelas eksperimen. Berdasarkan hasil analisis data diperoleh skor rata-rata hasil belajar siswa yang diajarkan dengan pembelajaran berbasis masalah sebesar 26,75 lebih tinggi dibandingkan dengan pembelajaran konvensional yaitu 20,65. Dari uji U Mann Whitney diketahui $\mathrm{Z}_{\mathrm{hitung}}=-3,97$ sedangkan $Z_{\text {tabel }}=-1,96$, artinya terdapat perbedaan yang signifikan antara skor rata-rata hasil belajar siswa pada kelas eksperimen dan kelas kontrol pada taraf 5\%. Nilai Effect Size yaitu 1,40 atau tergolong tinggi dan jika dilihat dari standar kurva normal, maka pembelajaran berbasis masalah memberikan kontribusi sebesar $41,92 \%$ terhadap hasil belajar siswa.
\end{abstract}

Kata kunci : model pembelajaran berbasis masalah, pembiasan cahaya pada lensa, hasil belajar.

$\begin{array}{ll}\begin{array}{c}\text { Pendidikan merupakan salah } \\ \text { komponen penting dalam }\end{array} & \begin{array}{l}\text { pembaruan pendidikan harus selalu } \\ \text { dilakukan untuk meningkatkan } \\ \text { kualitas pendidikan nasional. }\end{array} \\ \text { meningkatkan kualitas sumber daya } & \text { Sebagian besar dari siswa tidak } \\ \text { manusia. Untuk mewujudkan hal itu, } & \text { mampu menghubungkan antara apa } \\ \text { maka sekolah sebagai komponen } & \text { yang mereka pelajari dengan } \\ \text { utama pendidikan perlu mengelola } & \begin{array}{l}\text { yagaimana pengetahuan tersebut akan } \\ \text { pembelajaran sesuai dengan prinsip- }\end{array} \\ \text { prinsip Kegiatan Belajar Mengajar } & \begin{array}{l}\text { digunakan atau dimanfaatkan. Siswa } \\ \text { (KBM) antara lain: (1) kegiatan }\end{array} \text { memiliki kesulitan untuk memahami } \\ \text { berpusat pada siswa; (2) belajar } & \text { konsep akademik sebagaimana } \\ \text { melalui berbuat; dan (3) belajar } & \text { mereka biasa diajarkan, yaitu } \\ \text { mandiri dan belajar bekerja sama. } & \text { menggunakan sesuatu yang abstrak. } \\ \text { Sejalan dengan prinsip KBM tersebut, } & \text { Karena mereka membutuhkan } \\ \text { maka kegiatan pembelajaran } & \text { konsep-konsep yang berhubungan } \\ \text { diharapkan tidak terfokus pada guru, } & \text { dengan masyarakat pada umumnya } \\ \text { tetapi bagaimana mengaktifkan siswa } & \text { dimana mereka akan hidup dan } \\ \text { dalam belajarnya. Oleh karena itu, } & \text { bekerja. Persoalan-persoalan itu }\end{array}$


merupakan tantangan yang dihadapi oleh guru setiap hari dan tantangan bagi pengembangan kurikulum. Persoalan-persoalan tersebut diatasi dengan penerapan suatu paradigma baru dalam pembelajaran di kelas, yaitu pendekatan kontekstual.

\section{Pendekatan}

kontekstual merupakan suatu konsep belajar dimana guru menghadirkan situasi dunia nyata ke dalam kelas dan mendorong siswa membuat hubungan antara pengetahuan yang dimilikinya dengan penerapannya dalam kehidupan mereka sebagai anggota keluarga dan masyarakat. Pembelajaran kontekstual menempatkan siswa di dalam konteks bermakna yang menghubungkan pengetahuan awal siswa dengan materi yang sedang dipelajari dan sekaligus memperhatikan faktor kebutuhan individual siswa dan peranan guru. Salah satu fokus pendekatan kontekstual adalah model pembelajaran berbasis masalah (problem-based learning) (Nurhadi, 2004).

Pelajaran fisika sangat erat dengan pembelajaran berbasis masalah atau Problem Based Learning $(P B L)$. Hal ini disebabkan karena pemecahan masalah merupakan pusat pembelajaran fisika dan juga merupakan pembelajaran yang lebih menekankan pada pemecahan masalah atau masalah sebagai titik tolak. Dalam pembelajaran ini, siswa dapat menumbuhkan keterampilan menyelesaikan masalah, bertindak sebagai pemecah masalah dan dalam pembelajaran dibangun proses berpikir, kerja kelompok, berkomunikasi, dan saling memberi informasi. Selain itu model PBL dapat memberikan kesempatan pada siswa bereksplorasi mengumpulkan dan menganalisis data untuk memecahkan masalah, sehingga siswa mampu untuk berpikir kritis, analitis, sistematis dan logis dalam menemukan alternatif pemecahan masalah.

Dalam rangka mewujudkan tujuan pembelajaran fisika, maka menumbuhkan keterampilan berpikir siswa khususnya keterampilan berpikir kritis mutlak diperlukan. Siswa yang memahami konsep tidak hanya mampu menguasai sejumlah konsep yang telah dipelajarinya, tetapi ia mampu menerapkannya pada aspek lainnya dengan mengembangkan konsep berpikirnya.

Berdasarkan hasil wawancara dengan guru SMP 5 Ketapang, diperoleh informasi bahwa siswa mengalami kesulitan dalam memahami materi pembiasan cahaya pada lensa, khususnya dalam memahami sinar-sinar istimewa lensa cembung dan lensa cekung serta melukiskan pembentukan bayangan lensa cembung dan lensa cekung. Hal tersebut dibuktikan dengan rendahnya hasil belajar siswa kelas VIII SMP Negeri 5 Ketapang pada materi cahaya tahun ajaran 2008/2009 dengan rata-rata hasil belajar 58,31. Nilai rata-rata tersebut masih dibawah Kriteria Ketuntasan Minimal (KKM) yang telah ditetapkan oleh sekolah yaitu 60 .

Berdasarkan hasil observasi di SMP Negeri 5 Ketapang terlihat jelas guru mendominasi dalam pembelajaran, sedangkan siswanya lebih banyak diam. Setelah selesai menjelaskan materi, guru langsung memberi tugas kepada siswa untuk mengerjakan soal di buku paket. Dari 
pengamatan juga terlihat hanya sebagian siswa yang mengerjakan soal, sedangkan sebagiannya ada yang berbicara dengan teman sebangkunya, serta mengerjakan pekerjaan lain.

Berdasarkan uraian dan data di atas, penelitian ini dilakukan untuk menerapkan model pembelajaran berbasis masalah dalam materi pembiasan pada lensa di SMP Negeri 5 Ketapang. Dengan menerapkan model pembelajaran berbasis masalah dalam materi pembiasan cahaya pada lensa, siswa dapat mengaitkan materi yang diajarkan dengan situasi dunia nyata siswa dan menghubungkan pengetahuan yang dimiliki siswa dengan kehidupan sehari-hari agar siswa lebih mudah dalam memahami materi pembiasan cahaya pada lensa sehingga hasil belajar siswa meningkat.

Secara umum, masalah dalam penelitian ini adalah "Bagaimana pengaruh penerapan model pembelajaran berbasis masalah dalam materi pembiasan cahaya pada lensa terhadap hasil belajar siswa di kelas VIII SMP Negeri 5 Ketapang?". Masalah tersebut secara spesifik dibagi menjadi beberapa sub masalah.

Adapun sub masalah dalam penelitian ini adalah: 1) Bagaimana hasil belajar siswa untuk pembiasan cahaya pada lensa yang diajarkan dengan model pembelajaran berbasis masalah?, 2) Bagaimana hasil belajar siswa dalam materi pembiasan cahaya pada lensa yang diajarkan dengan model pembelajaran konvensional?, 3) Bagaimana perbedaan hasil belajar siswa terhadap penerapan model pembelajaran berbasis masalah dengan pembelajaran konvensional tentang pembiasan cahaya pada lensa?, 4) Seberapa besar pengaruh

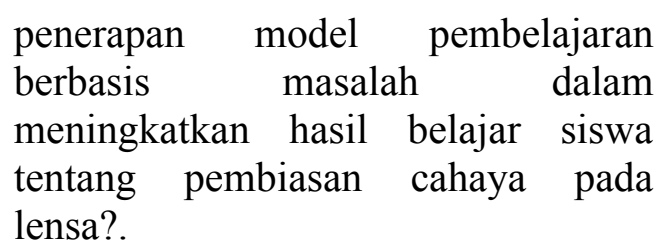

Tujuan umum penelitian ini untuk mengetahui pengaruh penerapan model pembelajaran berbasis masalah terhadap hasil belajar siswa dalam materi pembiasan cahaya pada lensa di kelas VIII SMP Negeri 5 Ketapang. Tujuan khusus dari penelitian ini adalah: 1) Mengetahui hasil belajar siswa dalam materi pembiasan cahaya pada lensa yang diajarkan dengan model pembelajaran berbasis masalah. 2) Mengetahui hasil belajar siswa dalam materi pembiasan cahaya pada lensa yang diajarkan dengan menggunakan pembelajaran konvensional. 3) Mengetahui perbedaan hasil belajar siswa terhadap penerapan model pembelajaran berbasis masalah dengan pembelajaran konvensional dalam materi pembiasan cahaya pada lensa. 4) Mengetahui seberapa besar pengaruh penerapan pembelajaran berbasis masalah terhadap hasil belajar siswa dalam materi pembiasan cahaya pada lensa.

Model pembelajaran berbasis masalah adalah suatu pendekatan pembelajaran yang menggunakan masalah dunia nyata sebagai suatu konteks bagi siswa untuk belajar tentang cara berfikir kritis dan keterampilan pemecahan masalah, serta untuk memperoleh pengetahuan dan konsep esensial dari materi pelajaran (Nurhadi, 2004). Model pembelajaran berbasis masalah merupakan suatu pembelajaran yang menuntut aktivitas mental siswa untuk memahami suatu konsep pembelajaran melalui situasi dan 
masalah yang disajikan pada awal pembelajaran. Masalah yang disajikan kepada siswa merupakan masalah dalam kehidupan sehari-hari (kontekstual).

Pembelajaran berbasis masalah secara khusus melibatkan siswa bekerja pada masalah dalam kelompok kecil yang terdiri dari 4-5 orang dengan bantuan asisten sebagai tutor. Masalah disiapkan sebagai konteks pembelajaran baru. Analisis dan penyelesaian terhadap masalah itu menghasilkan perolehan pengetahuan dan keterampilan pemecahan masalah. Permasalahan dihadapkan sebelum semua pengetahuan relevan diperoleh dan tidak hanya setelah membaca teks atau mendengar ceramah tentang materi subjek yang melatarbelakangi masalah tersebut. Guru berfungsi sebagai pelatih kelompok yang menyediakan bantuan agar interaksi siswa menjadi produktif dan membantu siswa mengidentifikasi pengetahuan yang dibutuhkan untuk memecahkan masalah. Hasil dari proses pemecahan masalah itu adalah siswa membangun pertanyaanpertanyaan (isu pembelajar-an) tentang jenis penyelidikan apa yang diperlukan untuk menyelesaikan masalah. Setelah itu, siswa melakukan penyelidikan pada isu-isu pembelajaran yang telah diidentifikasi dengan menggunakan berbagai sumber.

Temuan-temuan dari psikologi kognitif menyediakan landasan teoretis untuk meningkatkan pengajaran secara umum dan khsususnya problem based learning (PBL). Premis dasar dalam psikologi kognitif adalah belajar merupakan proses konstruksi pengetahuan baru yang berdasarkan pada pengetahuan terkini.

Berbagai pengembangan pengajaran berbasis masalah memberikan karakteristik untuk model pembelajaran PBL ini sebagai berikut:

a). Pengajuan pertanyaan atau masalah, Pembelajaran berdasarkan masalah mengorganisasikan pengajaran disekitar pertanyaan dan masalah yang kedua-duanya secara sosial penting dan secara pribadi bermakna bagi siswa. 2). Berfokus pada keterkaitan antar disiplin, Masalah yang akan diselidiki telah dipilih yang benar-benar nyata agar dalam pemecahannya siswa meninjau masalah itu dari banyak mata pelajaran. 3). Penyelidikan autentik, Pengajaran berbasis masalah mengharuskan siswa untuk melakukan penyelidikan autentik untuk mencari penyelesaian nyata terhadap masalah nyata. 4). Menghasilkan produk/karya dan memamerkannya, Pengajaran berbasis masalah menuntut siswa untuk menghasilkan produk tertentu dalam bentuk karya nyata atau artefak dan peragaan yang menjelaskan atau mewakili bentuk penyelesaian masalah yang mereka temukan. 5). Kerjasama Pembelajaran berbasis masalah dicirikan oleh siswa bekerja sama satu sama lain (paling sering berpasangan atau dalam kelompok kecil). Bekerja sama memberikan motivasi untuk secara berkelanjutan terlibat dalam tugas-tugas kompleks dan meperbanyak peluang untuk berbagi inkuiri dan dialog untuk mengembangkan keterampilan sosial dan keterampilan berfikir (Nurhadi, 2004). 
Pembelajaran berbasis masalah dirancang untuk membantu guru memberikan informasi sebanyakbanyaknya kepada siswa. Pembelajaran berbasis masalah dikembangkan terutama untuk membantu siswa mengembangkan kemampuan berfikir, pemecahan masalah, dan keterampilan intelektual; belajar tentang berbagai peran orang dewasa; dan menjadi pebelajar yang otonom dan mandiri (Nurhadi, 2004).

Tabel 1 Tahapan Model Pembelajaran Berbasis Masalah

\begin{tabular}{|l|l|}
\hline Tahap & Tingkah Laku Guru \\
\hline $\begin{array}{l}\text { Tahap I } \\
\text { Orientasi siswa kepada } \\
\text { masalah }\end{array}$ & $\begin{array}{l}\text { Guru menjelaskan tujuan pembelajaran, memotivasi } \\
\text { siswa untuk terlibat pada aktivitas pemecahan } \\
\text { masalah yang dipilihnya. }\end{array}$ \\
\hline $\begin{array}{l}\text { Tahap 2 } \\
\text { Menggorganisasi siswa } \\
\text { untuk belajar }\end{array}$ & $\begin{array}{l}\text { Guru membantu siswa mendefenisikan dan } \\
\text { mengorganisasikan tugas belajar yang berhubungan } \\
\text { dengan masalah tersebut. }\end{array}$ \\
\hline $\begin{array}{l}\text { Tahap 3 } \\
\text { Membimbing penyelidikan }\end{array}$ & $\begin{array}{l}\text { Guru mendorong siswa untuk menyimpulkan } \\
\text { informasi yang sesuai, melakukan eksperimen untuk } \\
\text { mendapatkan penjelasan dari pemecahan masalah. }\end{array}$ \\
\hline $\begin{array}{l}\text { Tahap 4 } \\
\text { Mengembangkan dan } \\
\text { menyajikan hasil karya }\end{array}$ & $\begin{array}{l}\text { Guru membantu siswa dalam merencanakan dan } \\
\text { menyiapkan hasil karya }\end{array}$ \\
\hline $\begin{array}{l}\text { Tahap 5 } \\
\text { Menganalisis dan } \\
\text { mengevaluasi proses } \\
\text { pemecahan masalah }\end{array}$ & $\begin{array}{l}\text { Guru membantu siswa untuk melakukan refleksi } \\
\text { atau evaluasi terhadap penyelidikan mereka dan } \\
\text { proses-proses yang mereka lakukan }\end{array}$ \\
\hline
\end{tabular}

( Sumber Ibrahim dan Nur, 2000)

Model konvensional merupakan suatu pembelajaran yang menitik beratkan pada peranan guru dalam penyampaian materi. Orientasi pembelajaran lebih bersifat content oriented. Pada model ini yang terpenting adalah expose atau pengkajian materi oleh guru yang berperan sebagai komunikator. Dalam sejarah pembelajaran konvensional ditandai dengan ceramah yang diiringi dengan penjelasan, serta pembagian tugas dan latihan.

Adapun langkah-langkah dalam pembelajaran konvensional adalah, Pendahuluan: 1) Guru mengucap salam dan mengecek kehadiran siswa, 2) Guru memberikan motivasi, 3) Guru menginformasikan materi yang akan dipelajari, 4) Guru menyampaikan tujuan pembelajaran. Kegiatan Inti: 1) Guru menyampaikan materi pelajaran, 2) Guru memberikan kesempatan kepada siswa untuk bertanya, 3) Guru memberikan soal latihan kepada siswa untuk dikerjakan. Penutup: 1) Guru bersama siswa menyimpulkan materi yang telah dipelajari, 2) Guru memberikan pekerjaan rumah (PR) kepada siswa dan menyuruh siswa untuk membaca materi selanjutnya di rumah. 


\section{Metode Penelitian}

Metode yang digunakan dalam penelitian ini adalah metode eksperimen. Tujuan dari penelitian eksperimen adalah untuk menyelidiki hubungan sebab akibat dengan cara memberikan perlakuan pada kelompok eksperimen dan penyediaan kelompok perbandingan.

Metode yang digunakan dengan bentuk penelitian eksperimen semu (Quasy Eksperiment). Metode rancangan yang digunakan dalam penelitian ini adalah Pretest Posttest Control Group Design. Populasi adalah keseluruhan subjek penelitian sebagai sumber data yang memiliki karakteristik tertentu di dalam suatu penelitian. Populasi dalam penelitian ini adalah siswa kelas VIII SMP Negeri 5 Ketapang

Teknik pengambilan sampel dilakukan dengan teknik Purposive Sampling yaitu dengan cara mengambil sampel bukan berdasarkan strata, random atau daerah, tetapi berdasarkan atas tujuan tertentu, dan beberapa pertimbangan dari peneliti sendiri sehingga dapat mewakili populasi. Untuk menentukan kelas kontrol dan kelas eksperimen dilakukan cabut undi yang didapat kelas VIII A sebagai kelas eksperimen dan kelas VIII B sebagai kelas kontrol. Pada kelompok eksperimen diberi pembelajaran dengan menggunakan model pembelajaran berbasis masalah, sedangkan pada kelompok kontrol diberi pembelajaran dengan menggunakan model pembelajaran konvensional.

Teknik pengumpulan data yang digunakan dalam penelitian ini adalah tekhnik pengukuran. Pengukuran yang dimaksud dalam penelitian ini adalah pemberian skor terhadap hasil belajar siswa dari tes (pre-test dan post-tes) yang diberikan pada kelas kontrol dan kelas eksperimen.

Instrumen penelitian yang digunakan dalam penelitian ini adalah tes. Tes yang digunakan dalam penelitian ini adalah tes tertulis berbentuk esai sebanyak 8 item soal. Validitas tes yang digunakan dalam penelitian ini adalah validitas isi. Suatu tes dapat dikatakan memiliki validitas isi yang tinggi apabila bahan tes sesuai dengan kurikulum, silabus dan buku pelajaran. Uji validitas isi dilakukan dengan membuat kisi-kisi soal test. Soal tes dikonsultasikan terlebih dahulu dengan pembimbing dan kemudian divalidasi oleh seorang dosen dan dua orang guru IPA Fisika kelas VIII SMP Negeri 5 Ketapang.

Hipotesis dalam penelitian ini adalah terdapat perbedaan antara hasil belajar siswa dalam materi pembiasan cahaya pada lensa di kelas VIII SMP Negeri 5 Ketapang yang diajarkan dengan model pembelajaran berbasis masalah dan model pembelajaran konvensional.

Perbandingan hasil belajar antara siswa kelas kontrol dan kelas eksperimen dapat dilihat dari hasil pre- test dan post-test. Hasil pre- test dan post-test siswa kelas kontrol dan kelas eksperimen dapat dilihat dalam tabel 2.

Berdasarkan tabel 2 dapat disimpulkan bahwa rata-rata skor pretest siswa pada kelas kontrol adalah 11,38, dan rata-rata skor pre-test siswa pada kelas eksperimen adalah 11,42. Data skor pre-test pada kelas eksperimen dan kelas kotrol dianalisis untuk melihat kemampuan awal siswa. Berdasarkan perhitungan uji normalitas skor pre-test kelas kontrol 
maupun kelas eksperimen, diperoleh $X_{\text {hitung }}^{2}>X_{\text {tabel }}^{2}$ dengan $X_{\text {tabel }}^{2} \quad(\alpha=$ $5 \%$ ) yaitu $X^{2}$ hitung sebesar 14,37 untuk kelas kontrol dan $X^{2}$ hitung sebesar 10,91 untuk kelas eksperimen.

Tabel 2 Hasil Pre-test dan Post-test siswa kelas kontrol dan kelas eksperimen

\begin{tabular}{|c|c|c|c|c|c|c|}
\hline \multirow{2}{*}{ No } & \multicolumn{3}{|c|}{ Kelas Kontrol } & \multicolumn{3}{|c|}{ Kelas Eksperimen } \\
\hline & $\begin{array}{l}\text { Kode } \\
\text { Siswa }\end{array}$ & Pre-Test & Post-test & $\begin{array}{l}\text { Kode } \\
\text { Siswa }\end{array}$ & Pre-Test & Post-test \\
\hline 1 & K-1 & 18 & 30 & E-1 & 20 & 34 \\
\hline 2 & $\mathrm{~K}-2$ & 10 & 27 & E-2 & 15 & 34 \\
\hline 3 & $\mathrm{~K}-3$ & 10 & 23 & E-3 & 9 & 24 \\
\hline 4 & $\mathrm{~K}-4$ & 7 & 16 & E-4 & 7 & 25 \\
\hline 5 & K-5 & 9 & 21 & E-5 & 10 & 28 \\
\hline 6 & $\mathrm{~K}-6$ & 18 & 23 & E-6 & 10 & 32 \\
\hline 7 & $\mathrm{~K}-7$ & 6 & 19 & E-7 & 23 & 34 \\
\hline 8 & K-8 & 3 & 16 & E-8 & 3 & 16 \\
\hline 9 & K-9 & 5 & 14 & E-9 & 18 & 32 \\
\hline 10 & K-10 & 12 & 25 & E-10 & 10 & 28 \\
\hline 11 & $\mathrm{~K}-11$ & 5 & 17 & E-11 & 8 & 19 \\
\hline 12 & $\mathrm{~K}-12$ & 8 & 18 & E-12 & 6 & 22 \\
\hline 13 & $\mathrm{~K}-13$ & 10 & 17 & E-13 & 10 & 24 \\
\hline 14 & K-14 & 10 & 16 & E-14 & 9 & 21 \\
\hline 15 & $\mathrm{~K}-15$ & 5 & 24 & E-15 & 17 & 30 \\
\hline 16 & $\mathrm{~K}-16$ & 15 & 17 & E-16 & 13 & 26 \\
\hline 17 & $\mathrm{~K}-17$ & 10 & 18 & E-17 & 15 & 28 \\
\hline 18 & $\mathrm{~K}-18$ & 15 & 16 & E-18 & 15 & 33 \\
\hline 19 & $\mathrm{~K}-19$ & 17 & 20 & E-19 & 8 & 32 \\
\hline 20 & $\mathrm{~K}-20$ & 11 & 24 & E-20 & 10 & 31 \\
\hline 21 & K-21 & 14 & 23 & E-21 & 8 & 24 \\
\hline 22 & $\mathrm{~K}-22$ & 10 & 22 & E-22 & 7 & 29 \\
\hline 23 & $\mathrm{~K}-23$ & 12 & 27 & E-23 & 12 & 27 \\
\hline 24 & $\mathrm{~K}-24$ & 13 & 23 & E-24 & 11 & 25 \\
\hline 25 & K-25 & 20 & 23 & & & \\
\hline 26 & $\mathrm{~K}-26$ & 23 & 30 & & & \\
\hline & $\Sigma$ & 296 & 549 & & 274 & 658 \\
\hline & $\bar{x}$ & 11.38 & 21.12 & & 11.42 & 27.42 \\
\hline & SD & 5,04 & 4,19 & & 4,76 & 4,37 \\
\hline
\end{tabular}


Karena $X_{\text {hitung }}^{2}>X_{\text {tabel }}^{2}$ maka kedua data tidak berdistribusi normal. Karena data tidak berdistribusi normal, maka digunakan uji statistik nonparametrik, yaitu $U$ mannWhitney. Berdasarkan uji U MannWhitney, diperoleh $-\mathrm{Z}_{\text {tabel }} \leq \mathrm{Z}_{\text {hitung }} \leq$ $\mathrm{Z}$ tabel, yaitu $-1,96 \leq-0,08<1,96$, berarti tidak terdapat perbedaan antara hasil pre-test kelas kontrol maupun kelas eksperimen dan kedua kelas dianggap memiliki kemampuan awal yang sama.

Karena kedua kelas memiliki kemampuan awal yang sama, maka untuk mengetahui perbedaan hasil belajar siswa antara kelas kontrol dan kelas eksperimen, dilakukan analisis skor post-test. Berdasarkan tabel 2 dapat disimpulkan bahwa rata-rata skor post-test siswa pada kelas kontrol adalah 21,12, dan rata-rata skor post-test siswa pada kelas eksperimen adalah 27,42. Dari hasil uji normalitas skor post-test kelas eksperimen diperoleh $X^{2}$ hitung sebesar 17,48 dengan $X_{\text {tabel }}^{2}(\alpha=5 \%)$ sebesar 5,99. Karena $X_{\text {hitung }}^{2}>X_{\text {tabel }}^{2}$ maka data tidak berdistribusi normal. Sedangkan data hasil post-test kelas kontrol diperoleh $X_{\text {hitung }}^{2}$ sebesar 7,76 dengan $X_{\text {tabel }}^{2}(\alpha=5 \%)$ sebesar 7,81 . Karena $X_{\text {hitung }}^{2}<X_{\text {tabel }}^{2}$ maka data berdistribusi normal (lampiran C-7). Karena salah satu kelas tidak berdistribusi normal, maka digunakan uji statistik nonparametrik, yaitu $U$ mann-Whitney. Berdasarkan uji $U$ Mann-Whitney, diperoleh $\mathrm{Z}_{\text {hitung }}<-\mathrm{Z}$ tabel, yaitu $-3,97<-1,96$, maka terdapat perbedaan antara hasil post-test kelas kontrol maupun kelas eksperimen. Hal ini berarti pembelajaran berbasis masalah dapat meningkatkan hasil belajar siswa pada materi pembiasan cahaya pada lensa di kelas VIII SMP Negeri 5 Ketapang.

Untuk mengetahui pengaruh pembelajaran berbasis masalah pada materi pembiasan cahaya pada lensa terhadap hasil belajar siswa di kelas VIII SMP Negeri 5 Ketapang, maka dihitung menggunakan effect size. Dari perhitungan, diperoleh harga effect size sebesar 1,40. Dengan menggunakan tabel distribusi normal maka diperoleh luas daerah sebesar 0,4192. Sehingga dapat disimpulkan bahwa pengaruh pembelajaran berbasis masalah terhadap hasil belajar siswa tergolong tinggi dengan memberikan sumbangan sebesar 41,92\%. Dari hasil pre-test dan posttest siswa baik kelas kontrol maupun kelas eksperimen, mengalami peningkatan hasil belajar setelah diberikan perlakuan. Peningkatan skor rata-rata pre-test dan post- test kelas kontrol dan kelas eksperimen dapat dilihat pada gambar 1 . 


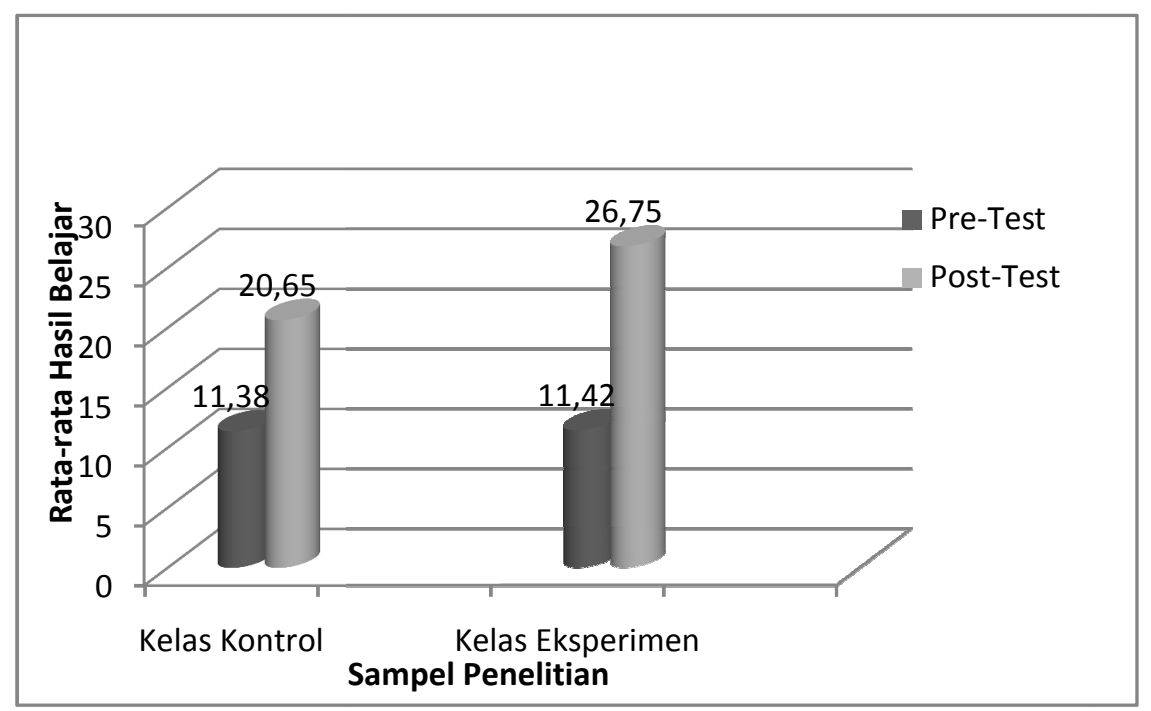

Gambar 1 Diagram pre-test dan post-test kelas eksperimen dan kelas kontrol

Berdasarkan Gambar 1 di atas menunjukkan bahwa terjadi peningkatan hasil belajar baik di kelas kontrol maupun eksperimen, dengan rata-rata perubahan skor pre-test dan post-test di kelas kontrol sebesar 9,27. Rata-rata perubahan skor pre-test dan post-test sebesar di kelas eksperimen 15,33. Setelah analisis hasil post-test, diketahui perbedaan hasil belajar siswa yang diajarkan dengan pembelajaran berbasis masalah di kelas eksperimen dengan pembelajaran konvensional di kelas kontrol.

Standar Ketuntasan Minimal (KKM) untuk mata pelajaran fisika di SMP Negeri 5 Ketapang yaitu 60 . Dari hasil post-test menunjukkan bahwa dari 26 siswa kelas kontrol yang diolah datanya, sebanyak 13 siswa (50\%) yang tidak tuntas dan 13 siswa $(50 \%)$ mencapai ketuntasan belajar. Sedangkan di kelas eksperimen dari 24 siswa kelas eksperimen yang diolah datanya, sebanyak 3 siswa $(12,5 \%)$ yang tidak tuntas dan 21 siswa $(87,5 \%)$ mencapai ketuntasan belajar. Dari hasil yang didapat, ternyata pada kelas kontrol tidak mencapai ketuntasan klasikal karena 50\% siswa tidak mencapai ketuntasan hasil belajar. Sedangkan untuk kelas eksperimen telah mencapai ketuntasan hasil belajar. Persentase ketuntasan kelas kontrol dan kelas eksperimen dapat dilihat pada gambar 2.

Berdasarkan gambar 2 terlihat besarnya persentase ketuntasan pada kelas eksperimen. Hal ini menunjukkan bahwa pembelajaran dengan pembelajaran berbasis masalah lebih baik bila dibandingkan dengan pembelajaran konvensional. Tingginya persentase etuntasan hasil belajar siswa kelas eksperimen disebabkan oleh beberapa hal, diantaranya dihadirkannya masalah autentik dalam proses pembelajaran, adanya LKS serta dilibatkannya siswa dalam diskusi kelompok kecil pada proses pembelajaran. 


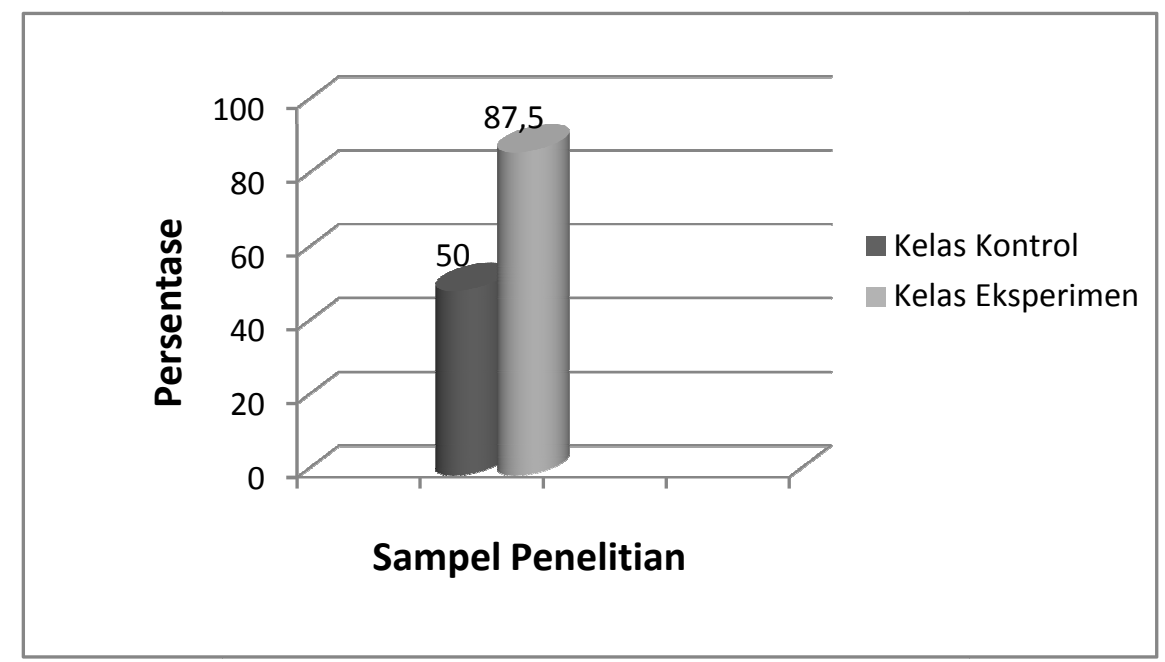

Gambar 2. Diagram persentase ketuntasan hasil belajar siswa di kelas kontrol dan kelas eksperimen.

Persentase siswa yang menjawab sangat kurang maksimal, kurang post-test pada kelas eksperimen dan maksimal, cukup maksimal, kelas kontrol disajikan dalam tabel 3.

maksimal dan sangat maksimal soal

TABEL 3 Persentase Post-test Siswa yang Menjawab Sangat Kurang Maksimal, Kurang Maksimal, Cukup Maksimal, Maksimal, dan Sangat Maksimal pada Kelas Eksperimen dan Kelas Kontrol Per Soal.

\begin{tabular}{|c|c|c|c|c|c|c|c|c|c|c|}
\hline \multirow{3}{*}{$\begin{array}{c}\text { Nomor } \\
\text { Soal }\end{array}$} & \multicolumn{10}{|c|}{ Persentase } \\
\hline & \multicolumn{5}{|c|}{ Kelas Eksperimen } & \multicolumn{5}{|c|}{ Kelas Kontrol } \\
\hline & SKM & KM & CM & $\mathrm{M}$ & SM & SKM & $\mathrm{KM}$ & $\mathrm{CM}$ & $\mathrm{M}$ & SM \\
\hline $1 \mathrm{a}$ & 0 & 4.17 & 4.17 & 33.33 & 58.33 & 0 & 3.85 & 69.23 & 23.07 & 3.85 \\
\hline $1 b$ & 0 & 0 & 4.17 & 33.33 & 62.50 & 0 & 7.69 & 69.23 & 11.54 & 11.54 \\
\hline $1 \mathrm{c}$ & 0 & 20.83 & 0 & 29.17 & 50 & 0 & 7.69 & 0 & 38.46 & 53.85 \\
\hline $1 \mathrm{~d}$ & 0 & 0 & 0 & 16.67 & 83.33 & 0 & 0 & 0 & 34.62 & 65.38 \\
\hline $2 a$ & 0 & 20.83 & 29.17 & 45.83 & 4.17 & 0 & 42.31 & 34.62 & 19.22 & 3.85 \\
\hline $2 b$ & 0 & 4.17 & 37.50 & 33.33 & 25 & 7.69 & 38.46 & 42.31 & 7.69 & 3.85 \\
\hline $2 \mathrm{c}$ & 0 & 70.83 & 0 & 25 & 4.17 & 30.77 & 42.31 & 0 & 19.23 & 7.69 \\
\hline $2 d$ & 0 & 0 & 0 & 41.67 & 58.33 & 0 & 30.77 & 0 & 23.08 & 46.15 \\
\hline
\end{tabular}

Keterangan:

SKM : Sangat Kurang Maksimal

KM : Kurang Maksimal

CM : Cukup Maksimal

Berdasarkan tabel 3 terdapat 8 item soal, dimana rata-rata pada semua item soal kelas eksperimen persentase siswa yang sangat maksimal lebih tinggi dari kelas kontrol. Hanya pada soal nomor 1c dan 2c saja persentase siswa yang
M : Maksimal

SM : Sangat Maksimal

menjawab sangat maksimal di kelas kontrol lebih tinggi dari kelas eksperimen. Hal ini dapat dilihat dari analisis persentase ketuntasan per soal post-test kelas kontrol dan kelas eksperimen gambar 3 dan 4. 


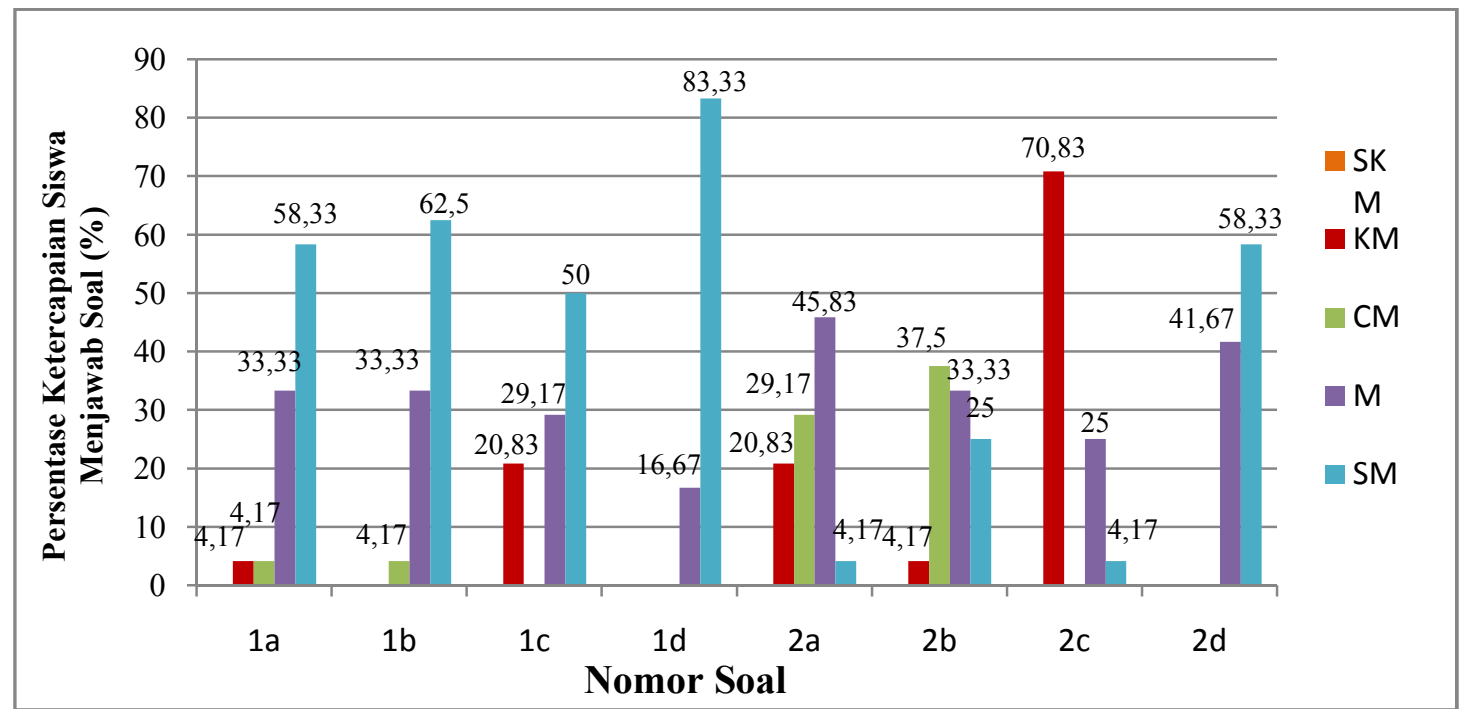

Keterangan: SKM (Sangat Kurang Maksimal), KM (Kurang Maksimal), CM (Cukup Maksimal), M (Maksimal), SM (Sangat Maksimal).

Gambar 3 Diagram persentase siswa yang menjawab sangat kurang maksimal, kurang maksimal, cukup maksimal, maksimal dan sangat maksimal per soal post-test kelas eksperimen.

Dari tabel 3 terlihat bahwa pada soal nomor 1a dan 2 a yaitu menggambarkan proses pembentukan bayangan pada lensa cembung dan lensa cekung, persentase siswa yang menjawab sangat maksimal di kelas eksperimen adalah $58,33 \%$ dan $4,17 \%$ (Gambar 4) sedangkan kelas kontrol adalah 3,85\% dan 3,85\% (Gambar 3). Tingginya persentase siswa yang menjawab sangat maksimal di kelas eksperimen dikarenakan siswa diajarkan dengan pembelajaran berbasis masalah, sehingga dapat mengembangkan kemampuan berfikir untuk menganalisis proses pembentukan bayangan pada lensa cembung dan lensa cekung dengan bantuan wacana yang diberikan guru dan buku paket pegangan siswa saat mereka diskusi. Hal ini sejalan dengan yang dikemukakan Ibrahim dan Nur (2000) bahwa pembelajaran berbasis masalah membantu siswa mengembangkan kemampuan ber- fikir, pemecahan masalah dan keterampilan intelektual.

Pada soal post-test nomor $1 \mathrm{~b}$ dan $2 \mathrm{~b}$, yaitu menghitung jarak bayangan pada lensa cembung dan lensa cekung, persentase siswa yang menjawab sangat maksimal di kelas eksperimen lebih tinggi dari kelas kontrol (Gambar 3 dan Gambar 4). Tingginya persentase siswa yang menjawab sangat maksimal di kelas eksperimen dikarenakan siswa diajarkan dengan pembelajaran berbasis masalah melalui diskusi untuk memecahkan masalah yang disajikan sehingga dapat menggali lebih banyak dalam menganalisis perhitungan jarak bayangan pada lensa cembung dan lensa cekung. Sejalan dengan pernyataan Maiyer (1983) bahwa melalui diskusi siswa mendapat kesempatan untuk melatih keterampilan berkomunikasi dan keterampilan untuk mengembangkan 
strategi berfikir dalam memecahkan masalah. Sementara di kelas kontrol siswa hanya mendengar penjelasan guru sehingga guru sukar mengetahui sampai di mana batas kemampuan para murid dalam memahami materi yang disampaikan akibatnya siswa tidak dapat dengan sangat maksimal menjawab soal post-test. Hal ini sejalan dengan pernyataan Alipandie (1984) bahwa salah satu kelemahan metode ceramah adalah guru sukar mengetahui sampai di mana batas kemampuan para murid dalam memahami bahan-bahan yang telah dibicarakan.

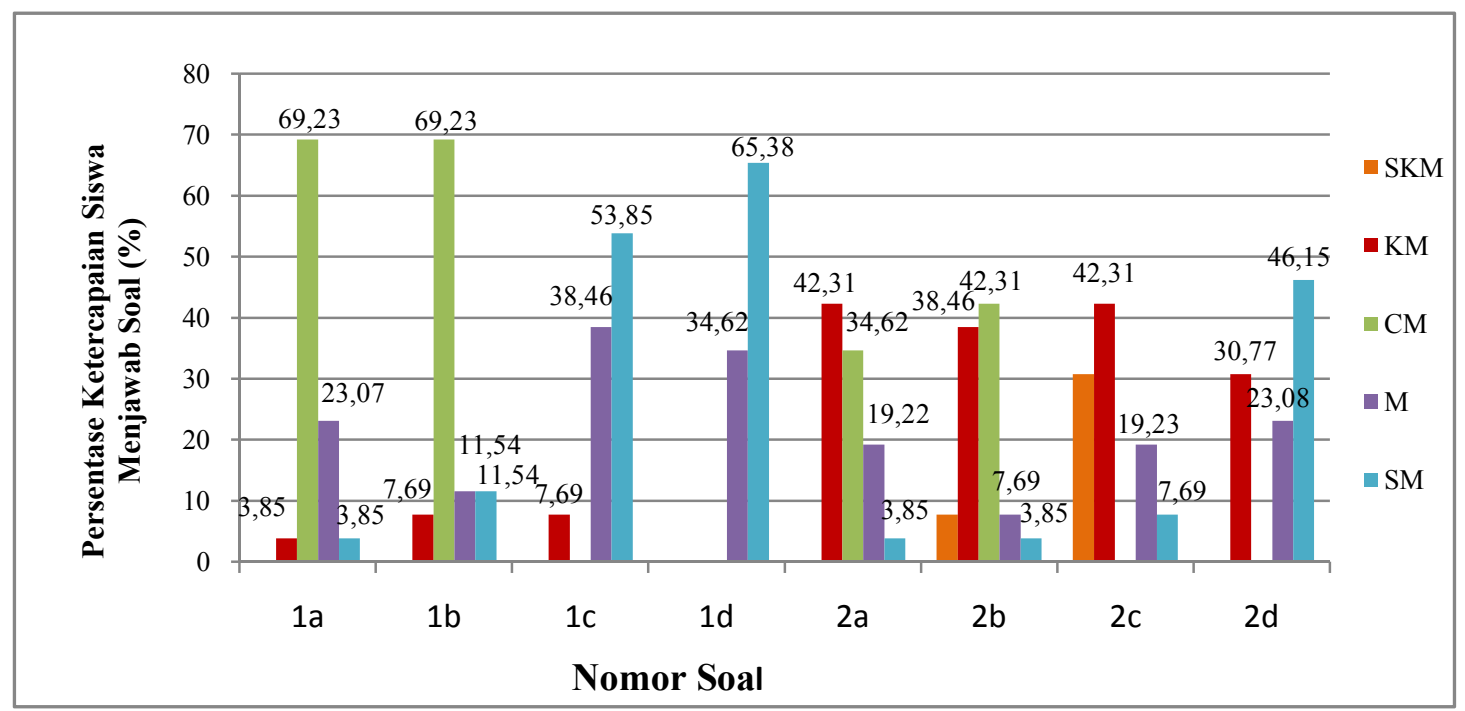

Keterangan: SKM (Sangat Kurang Maksimal), KM (Kurang Maksimal), CM (Cukup Maksimal), M (Maksimal), SM (Sangat Maksimal).

Gambar 4 Diagram persentase siswa yang menjawab sangat kurang maksimal, kurang maksimal, cukup maksimal, maksimal dan sangat maksimal per soal post-test kelas kontrol.

Pada soal post-test nomor 1c dan 2c, yaitu menghitung tinggi bayangan pada lensa cembung dan menghitung perbesaran bayangan pada lensa cekung, persentase siswa yang menjawab sangat maksimal di kelas eksperimen adalah $50 \%$ dan 4,17\% (Gambar 4) sedangkan kelas kontrol adalah 53,85\% dan 7,69\% (Gambar 3). Tingginya persentase siswa yang menjawab sangat maksimal di kelas kontrol karena guru mengajarkan cara perhitungan kepada siswa, sedangkan pada kelas eksperimen siswa memecahkan masalah mengenai perhitungan tinggi bayangan pada lensa cembung dan menghitung perbesaran bayangan pada lensa cekung yang terdapat LKS dengan bantuan wacana dan buku paket pegangan siswa. Untuk soal post-test nomor $1 \mathrm{~d}$ dan $2 \mathrm{~d}$, yaitu menyebutkan sifat bayangan pada lensa cembung dan lensa cekung, persentase siswa yang menjawab sangat maksimal di kelas eksperimen adalah $83,33 \%$ dan 58,33\% (Gambar 4) sedangkan kelas kontrol adalah $65,38 \%$ dan 46,15\% (Gambar 3). Tingginya persentase siswa yang 
menjawab sangat maksimal di kelas eksperimen karena siswa diajarkan dengan pembelajaran berbasis masalah dengan bantuan LKS. LKS mendorong siswa untuk berdiskusi dalam memecahkan masalah yang disajikan. Sesuai dengan pernyataan Rescha (2007) bahwa LKS sebagai penunjang untuk meningkatkan aktivitas siswa dalam proses belajar dapat mengoptimalkan hasil belajar. Selain itu juga soal nomor $1 \mathrm{~d}$ dan $2 \mathrm{~d}$ erat hubungannya dengan soal nomor 1a dan 2a. Siswa harus bisa menganalisis soal nomor $1 \mathrm{a}$ dan $2 \mathrm{a}$ untuk bisa menjawab soal nomr $1 \mathrm{~d}$ dan 2 d. Untuk mengetahui pengaruh pembelajaran berbasis masalah pada materi pembiasan cahaya pada lensa terhadap hasil belajar siswa di kelas VIII A SMP Negeri 5 Ketapang, maka dihitung menggunakan effect size. Dari perhitungan, diperoleh harga effect size sebesar 1,42. Maka besarnya effect size tergolong tinggi karena ES $>0,8(1,40>0,8)$. Dengan menggunakan tabel distribusi normal maka diperoleh luas daerah sebesar 0,4192 . Sehingga dapat disimpulkan bahwa pengaruh pembelajaran berbasis masalah terhadap hasil belajar siswa pada materi pembiasan cahaya pada lensa terhadap hasil belajar siswa di kelas VIII A SMP Negeri 5 Ketapang tergolong tinggi dengan memberikan sumbangan sebesar $41,92 \%$.

Berdasarkan analisis data hasil belajar siswa kelas kontrol (VIII A) dan kelas eksperimen (VIII B) SMP Negeri 5 Ketapang pada materi pembiasan cahaya pada lensa, maka dapat ditarik kesimpulan sebagai berikut: 1) Rata-rata hasil belajar siswa pada materi pembiasan cahaya pada lensa yang diajarkan dengan pembelajaran berbasis masalah adalah sebesar 26,75. 2) Rata-rata hasil belajar siswa pada materi pembiasan cahaya pada lensa yang diajarkan dengan pembelajaran konvensional adalah 20,65. 3) Terdapat perbedaan hasil belajar siswa kelas VIII SMP Negeri 5 Ketapang, antara siswa yang diajar menggunakan pembelajaran berbasis masalah dan siswa yang diajarkan dengan pembalajaran konvensional. Hal ini ditunjukkan dengan perhitungan statistik uji $U$ Mann Whitney pada taraf nyata 5\% diperoleh $Z_{\text {hitung }}<-Z_{\text {tabel }}(-3,97<-$ 1,96), maka $\mathrm{Ha}$ diterima. 4) Berdasarkan perhitungan effect size diperoleh harga sebesar 1,40, dengan menggunakan tabel distribusi normal diperoleh luas daerah sebesar 0,4192. Hal ini menunjukkan pengaruh pembelajaran berbasis masalah terhadap hasil belajar siswa kelas VIII A SMP Negeri 5 Ketapang tergolong tinggi, dengan memberikan sumbangan sebesar $41,92 \%$.

\section{DAFTAR PUSTAKA}

Alipandie, I. 1984. Didaktik Metodik Pendidikan Umum. Surabaya : Usaha Nasional

Anonim. 2010. Alat-alat Optik. (Online). (http://sidikpurnomo.net/alat -alat-optik.html di akses 09 Mei 2010)

2010. Artikel. (Online). (http://www.berani.co.id/Art ikel_Detail. aspx?ID $=2159 \&$ URLView $=$ Arsip_Laporan_Khusus.asp $x$ di akses 09 Mei 2010) 2010. Pembelajaran Berbasis Masalah. (Online). (http://lubisgrafura.wordpres 
s.com/2007/09/19/pembelaja ran-berbasis-masalah/ di akses 16 februari 2010)

Arikunto, S. 1987. Dasar-Dasar Evaluasi Pendidikan. Jakarta. Bina Aksara 2006. Prosedur Penelitian Suatu Pendekatan Praktik. Jakarta : Rineka Cipta

Dimar, R. 2006. Upaya Meningkatkan Hasil Belajar Siswa Kelas VIII $F \quad$ SMP Negeri 01 Ketanggungan Brebes pada Pokok Bahasan Teorema Pythagoras melalui Diskusi dalam Kelompok-kelompok Kecil. (online).

(http://digilib.unnes.ac.id/gs $\mathrm{dl} /$ collect/skripsi/index/asso c/HASHeb15/5f53a33e.dir/d oc.pdf diakses tgl $30 \quad 11$ 2009)

Djarwanto. 1995. Statistik Nonparametrik. Bandung: Alfabeta

Ibrahim dan Nur. 2000. Pengajaran Berdasarkan Masalah. Surabaya : University Press

Jihad, A dan Haris. 2007. Evaluasi Pembelajaran. Yogyakarta: Multi Pressindo

Kanginan, M. 2007. IPA Fisika Untuk Kelas VIII. Jakarta: Erlangga

Nawawi, Hadari. 2003. Metode Penelitian Bidang Sosial. Yogyakarta : Gajah Mada University Press

Nazir, M. 1988. Metode Penelitian. Jakarta : Rineka Cipta

Nurhadi, dkk. 2004. Pembelajaran Kontekstual dan Penerapannya dalam $K B K$. Surabaya : Universitas Negeri Malang
Nurhayati, N. 2007. Ringkasan dan Bank Soal Sains Fisika Untuk SMP/MTs. Bandung : Yrama Widya

Poerwadarminta, W.J.S. 2003. Kamus Umum Bahasa Indonesia. Jakarta : Balai Pustaka

Subana, Rahadi, M. \& Sudrajat. 2000. Statistik Pendidikan. Bandung: Pustaka Setia

Sugiyono. 2006. Metode Penelitian Pendidikan. Bandung : Alfabeta

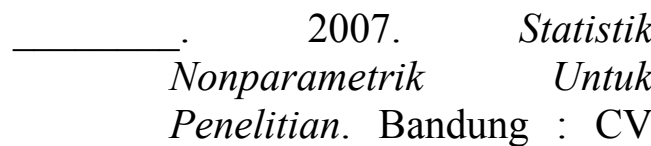
Alfabeta . 2008. Metode Penelitian Pendidikan(Pendekatan Kuantitatif, Kualitatif, $R \& D)$. Bandung : $\mathrm{CV}$ Alfabeta

Sutrisno, L. 2001. Konfirmasi Data. (Online). (http://www.scribd.com/ document downloads/45960 08 ? secret pasword $=$ \&extens ion=ppt, diakses 12 Januari 2010)

Usman dan Purnomo. 2006. Pengantar Statistik. Jakarta : PT Bumi Aksara

Winataputra, U. \& Rosita, T. 1994. Belajar dan Pembelajaran. Jakarta : Depdikbud Universitas Terbuka 